\title{
Effect of Drain Depth of Vertisols, Nitrogen Source and Time of Application on Yield and Yield Components of Maize (Zea Mays L.) in Ambo, Western Ethiopia
}

\author{
${ }^{1}$ Tadesse Debele $\&{ }^{2}$ Bobe Bedadi \\ ${ }^{1}$ Department of Plant Sciences, College of Agriculture and Veterinary Sciences, \\ Ambo University, Ethiopia \\ ${ }^{2}$ School of Natural Resource Management and Environmental Sciences, \\ Haramaya University, Ethiopia \\ tadesse_2007@yahoo.com
}

\begin{abstract}
Highland soils are mostly Vertisols which is characterized by low content of nitrogen and are generally waterlogged due to abundant rainfall. With this view a field study was conducted at Ambo Agriculture Research Center experimental site during the main cropping season of 2013-2014, with the aim to determine the effects of drain depth on root depth (RD), yield and yield components of maize grown on Vertisols and to identify appropriate nitrogen source and time of application for maize production. The treatment was arranged factorial with five drain depths $(0,15,30,45$ and $60 \mathrm{~cm})$, two nitrogen $(N)$ sources (urea and ammonium sulfate) and two timings of $N$ applications (twice and thrice). The experiment was laid out in Randomized Complete Block Design (RCBD) with three replications. The results revealed that drain depths, 45 and $60 \mathrm{~cm}$ deep resulted in deeper root system and higher grain and stover yield than drain depths of 0,15 and $30 \mathrm{~cm}$. Grain and stover yields, 1000 grain weight and harvest index $(H I)$ were highly significantly $(P \leq 0.05)$ affected by drain depths, nitrogen sources and time of application, and the interaction effect of drain depths and $N$ source. The maximum grain yield (6.33 $\left.\mathrm{tha}^{-1}\right)$, stover yield $\left(7.57 \mathrm{th \textrm {a } ^ { - 1 }}\right), 1000$ grains weight $(423.83 \mathrm{~g})$ and $\mathrm{HI}$ $(44.80 \%)$ were obtained from drain depth of $60 \mathrm{~cm}$ coupled with thrice split application of ammonium sulfate (AS). However, the above yields are on par with $45 \mathrm{~cm}$ deep drain. Similarly, thrice split application of $N$ source gave better grain and stover yields, 1000 grain weight and HI than twice at 45 and $60 \mathrm{~cm}$ drain depths and the lowest were obtained from undrained plots $(0 \mathrm{~cm})$. Hence, drain depth of $45 \mathrm{~cm}$ coupled with ammonium sulfate and thrice split application could enhance maize production on Vertisols in Ambo and similar areas.
\end{abstract}

Keywords: Vertisols, Drain Depth, Nitrogen, Maize, Yield

\section{INTRODUCTION}

Maize (Zea mays L.) is one of the principal food crops in Ethiopia. According to CSA (2010), maize occupied 2.1 million hectares (ha) of land with estimated average yield of 2.9 tons (t) ha ${ }^{-1}$. This is far below the world average of $5.1 \mathrm{t} \mathrm{ha}^{-1}$ (FAO, 2008). One of the major constraints of maize production and productivity is inadequate soil and crop management practices.

In Ethiopia, maize is being cultivated across a number of agro-ecological zones (AEZ). Each AEZ zone is characterized by agro-climatic factors (principally moisture availability) and differentiated by soil patterns (Jaetzold and Schmidt, 1992). Vertisols occupy approximately 12.6 million ha, or about $10 \%$ of the land mass of the country (Berhanu, 1985). Of the total area, 70\% of Vertisols are found in the highlands, and about 25\% (2.21 million ha) of the highland Vertisols are cropped and some 6 million ha are left under native pasture because of severe drainage problems in the main rainy season (Berhanu, 1985; Jutzi et al., 1987). Drainage is essential practice for all Vertisols in high rainfall areas which are prone to flooding (Sigunga et al., 2002).

Nitrogen has been reported to be the most limiting nutrient limiting crop production particularly in Vertisols in Ethiopia (Mesfin, 1980; Tekelign et al., 1988), and $\mathrm{N}$ use by farmers is also minimal due to high purchase value which is beyond the capacity of most maize growers (Bedru et al., 2012). Besides, there is a widespread concern by farmers that crops in general, and cereals in particular, do not respond well to $\mathrm{N}$ application in Vertisols. The low crop response to $\mathrm{N}$ is due to $\mathrm{N}$ losses through leaching/bypass flow (Andrieni and Steenhuis, 1990; Barraclough et al., 1992), and/or denitrification (Aulakh et al., 1992). Ttherefore, there is a need to synchronize cultivation and fertilizer application with appropriate soil moisture content on Vertisols. 
At Ambo, crop production is constrained mainly by waterlogging and low soil $\mathrm{N}$ status (Bayene, 1988; Engdawork, 2002). A lot of works have done to tackle the waterlogging problems of the Vertisols in the central highlands of Ethiopia for about two decades. However, there is low adoption of the Vertisols management technologies by the small scale farmers due to lack of compatibility of technologies with the farmers' socio-economic conditions. Regardless of lack of adoptions of improved management technologies, Vertisols sustain the lives of millions of people with the old traditional management techniques and so became an obstacle to achieve food self sufficiency in Ethiopia.

Although there has been concern over waterlogging incidences in relation to reduction of crop yields in Vertisols at Ambo, no consideration has been given to define appropriate drain depth in relation to maize crop and efficient use of fertiliser $\mathrm{N}$. Therefore, the objectives of this study were to determine the effects of drain depth on root depth and yields of maize and to identify appropriate nitrogen fertilizer source for maize production in Vertisols at Ambo.

\section{Materials AND Methods}

\subsection{Description of the Study Area}

A field experiment was conducted at Ambo Agriculture Research Center during main cropping season of 2013-2014. The site has been chosen to represent the study area and for ease of operation. The study site is located in west Shoa zone of Oromia National Regional State, central Ethiopia. Ambo Agriculture Research Center is located at $126 \mathrm{~km}$ west of Addis Ababa and located $8^{0} 55^{\prime}$ north and $38^{\circ} 07^{\prime}$ east at an altitude of 2225 meters above sea level (m.a.s.l). The soil type of the study area is Pellic Vertisols (FAO class) (Morton, 1977). The slope of the study area ranges from 0.1 to $1 \%$.

\subsection{Experimental Field Layout}

A field experiment was laid out in a Randomised Complete Block Design (RCBD) with three replications. The treatments composed of five drain depths from soil surface $(0,15,30,45$ and 60 $\mathrm{cm}$ ), two $\mathrm{N}$ sources and two times of applications. The two $\mathrm{N}$ sources (urea and ammonium sulphate) were combined in a complete factorial arrangement. Nitrogen from urea and ammonium sulphate (AS) was applied at the recommended rate of $92 \mathrm{~kg} \mathrm{~N} \mathrm{ha}^{-1}$ for maize, and all treatments received the recommended phosphorus rate of $20 \mathrm{~kg} \mathrm{P} \mathrm{ha}^{-1}$ in the form of triple super phosphate (TSP). Urea and AS fertilizers were applied in twice and thrice split, viz. half at sowing and half at 35 days after sowing when maize was at knee-height stage, and 1/3 at sowing, 1/3 at 35 days after sowing when maize is at knee-height stage and $1 / 3$ at flowering stage of maize crop, respectively. All TSP was applied in a band at sowing.

\subsection{Cultural Practices and Planting Materials}

Land cultivation is almost exclusively done by oxen-drawn implements. To overcome cultivation difficulties, seedbed preparation for all crops in the Ethiopian highlands starts with two ploughings during the short rainy season (March/April), when workability is relatively good. For maize, two or three ploughings are considered sufficient.

Open drains were formed manually using hoes and spade, measured and adjusted to the required drain depths. Highland maize hybrid Jibat (AMH851) which is released for highland agro-ecologies was planted on May 17, and harvested on December 23, 2013. This variety is widely grown in this area. The maize hybrid was planted in 6 rows of $5.0 \mathrm{~m}$ long with inter- and intra-row spacing of 0.75 and $0.25 \mathrm{~m}$, respectively. Plots within a block were separated by $1 \mathrm{~m}$ space and blocks separated by a $2 \mathrm{~m}$ path. One plant per hill was maintained after thinning, comprising plant population of 53,333 plants $\mathrm{ha}^{-1}$. The recommended weed control practice for maize (i.e., twice hand weeding at 30 and 55 days after sowing) was followed and slashing at milk stage was adopted.

\subsection{Data Collection}

Data on yield, yield components and growth parameters were obtained from the central three rows of each plot. The plant density of every plot was counted at physiological maturity before harvesting. Plant height was recorded from the base of the plant at ground level to the base of tassel from five randomly selected plants at flowering stage. Grain yields were obtained from the harvested three rows of each plot area. Moisture content of the grains was measured at harvest time and maize grain yield was adjusted to the standard moisture content of $12.5 \%$. At harvest, biomass (above ground portion) 
was obtained. Total biomass was calculated as the sum of grain and stover yields, and harvest index was calculated as the ratio of grain yield to total biomass and expressed in percentage. The weight of 1000 maize seed was weighed and recorded.

The root depth (RD), that is the vertical length of the longest root, was measured at silking stage using a measuring tape. One row of maize next to border row was used for RD measurement. The measurement was taken in situ directly under the plant. Rooting depths of five plants per plot was measured and the arithmetic mean was taken as the RD for the treatment.

\subsection{Data Analysis}

Data on yield, yield components and growth parameters of maize were collected and managed properly using the Excel computer software. The collected data was subjected to the analysis of variance using the SAS program version 8.2 (SAS Institute, 2001). Treatment means for each parameter were separated by Duncan's Multiple Range Test (DMRT) and Least Significant Difference (LSD) test at $\mathrm{P}=0.05$.

\section{RESULTS AND DISCUSSION}

\subsection{Plant Height}

The analysis of variance indicated that maize plant height was significantly $(\mathrm{P}<0.01)$ influenced by drain depth (Table 1). However, $\mathrm{N}$ source and timing, and the interaction effect of drain depth, $\mathrm{N}$ source and time of application were not significant for the same parameter.

The maximum plant height $(227.0 \mathrm{~cm})$ was obtained at the deeper drain depth of $60 \mathrm{~cm}$, whereas the least value $(170.5 \mathrm{~cm})$ was recorded in plots where no drain provided. In the present study, increase in plant height particularly at deep drains of 45 and $60 \mathrm{~cm}$ can be attributed to well aeration of the soil at rooting depth of maize plants. Plant population had a significant effect on plant height. Maximum and minimum plant height was recorded from the treatments of 51851 and 42814 plants ha $^{-1}$, respectively. These results are in agreement with (Hassen, 2000) who reported that plant height deceased with low planting density and vice versa.

Application of $\mathrm{N}$ fertilizers from $\mathrm{NH}_{4} \mathrm{SO}_{3}$ resulted in taller plant height than from urea even though statistically not significant. Similarly, though not significant three times split application of N revealed higher plant height than twice split application. These results are supported by Brown and Scott (1984) who also stated that there exists a functional equilibrium between root and shoot system of annual crops such that a significant change in root growth is transmitted to the shoot and affects the shoot growth, and vice versa.

Table 1. Main effects of drain depth on plant height, plant density and root depth of maize grown on Vertisols at Ambo

\begin{tabular}{|l|l|l|l|}
\hline $\begin{array}{l}\text { Drain depth } \\
(\mathrm{cm})\end{array}$ & $\begin{array}{l}\text { Plant density } \\
\left(\mathrm{ha}^{-1}\right)\end{array}$ & $\begin{array}{l}\text { Plant height } \\
(\mathrm{cm})\end{array}$ & $\begin{array}{l}\text { Root depth } \\
(\mathrm{cm})\end{array}$ \\
\hline 0 & $42814 \mathrm{c}$ & $170.50 \mathrm{~d}$ & $23.72 \mathrm{~b}$ \\
\hline 15 & $48148 \mathrm{~b}$ & $194.67 \mathrm{c}$ & $26.30 \mathrm{~b}$ \\
\hline 30 & $48962 \mathrm{~b}$ & $214.83 \mathrm{~b}$ & $34.27 \mathrm{a}$ \\
\hline 45 & $50962 \mathrm{a}$ & $222.67 \mathrm{a}$ & $38.33 \mathrm{a}$ \\
\hline 60 & $51851 \mathrm{a}$ & $227.00 \mathrm{a}$ & $38.65 \mathrm{a}$ \\
\hline LSD $(0.05)$ & 1482 & 8.44 & 5.62 \\
\hline S.E. $( \pm)$ & 470.45 & 2.68 & 1.78 \\
\hline C.V. $(\%)$ & 9.28 & 9.74 & 13.45 \\
\hline
\end{tabular}

Means within a column followed by the same letter(s) are not significantly different at $5 \%$ probability.

\subsection{Maize Plant Density}

Maize plant density was significantly influenced $(\mathrm{P}<0.01)$ by drain depths (Table 1$)$. However, $\mathrm{N}$ source and timing, and the interaction effect of drain depth, $\mathrm{N}$ source and time of application were not significant.

Drains had significant impact on maize plant density in waterlogging Vertisols. The highest plant

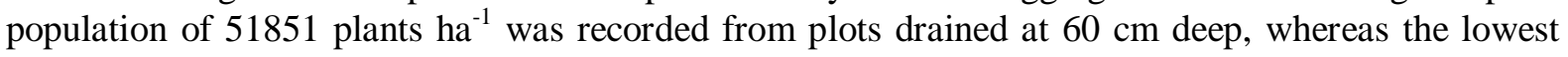


density (42814 plants ha $^{-1}$ ) was recorded in undrained plots, with decrease of about $17.43 \%$ in stand count of maize plant compared to deep drain depth of $60 \mathrm{~cm}$. Hence, the highest plant population at deep drain depth of 45 and $60 \mathrm{~cm}$ resulted in improved yield in maize as indicated in table 1 and 2 . Several other studies reported that plant population is a key factor for attaining maximum grain yield (Esechie, 1992; Akbar et al., 2002; Trenton et al., 2006).

\subsection{Root Depth}

Drain depth was highly significant $(\mathrm{P}<0.01)$ on root depth of maize grown on Vertisols (Table 1$)$. However, $\mathrm{N}$ source and timing, and the interaction effect of drain depth, $\mathrm{N}$ source and time of application were not significant.

Drainage is one of the possible management measures to control soil moisture content in the root environment. In waterlogging Vertisols, drainage creates a favorable environment for root development. Moreover, drainage had positive influence on rooting depth of maize in this study. The highest root depth $(38.65 \mathrm{~cm})$ was recorded in drain depth of $60 \mathrm{~cm}$. However, the lowest root depth $(23.72 \mathrm{~cm})$ was observed in plots with no drain provided, with decrease of about $38.6 \%$ in root depth of maize plant compared to deep drain depth of $60 \mathrm{~cm}$ at silking stage.

In general, the provision of drains 45 and $60 \mathrm{~cm}$ deep was necessary in reducing soil moisture content in the $0-60 \mathrm{~cm}$ profile within which maize roots proliferate. Consequently, root growth was promoted and grain yield was increased. This is in agreement with the finding of Asiedu and Bonsu (2001), who also reported that removal of excess water through drainage improves root-zone aeration of the soil, root development and plant growth and yield, as far as there is sufficient available soil moisture in the soils. A similar result was also reported by Sigunga et al. (1997) the drains 40 and $60 \mathrm{~cm}$ deep led to deeper root depth and higher yields of maize. Smaling and Bouma (1992) found that maize rooting depth in a Vertisols in Kenya did not extend to below $40 \mathrm{~cm}$ soil depth where drainage was not provided. In the present study, it was observed that maize root depth extended, like, to $38 \mathrm{~cm}$ deep, the determining factor being soil aeration. Soil aeration, in turn, is determined by soil moisture content, which is controlled by drain and rainfall pattern.

\section{YIELD}

\subsection{Grain Yield}

The analysis of variance indicated that maize grain yield was significantly $(\mathrm{P}<0.05)$ affected by drain depth, nitrogen source and timing, and the interaction between drain depth and nitrogen sources (Table 2). However, the interaction between drain depth and nitrogen timings, and drain depth, $\mathrm{N}$ sources and time of applications were not significant. In general, grain yields increased with increasing drain depth. There was a significant difference in yields obtained from plots with different drain depth. The yields from plots 45 and $60 \mathrm{~cm}$ deep drains were significantly higher than those from plots with 0,15 and $30 \mathrm{~cm}$ deep drains. Thus, the lower productivity of the crops in the plots with no and shallow drains are attributable to unfavorable root growth conditions created by high soil moisture contents. In the present experiment, soil hydrological properties especially low infiltration rate facilitating water logging conditions, and management component essentially water control by drainage interact, consequently affecting denitrification $\mathrm{N}$ losses and uptake of nutrients. These results are in agreement with Muchena and Ikitoo (1992) who found that lower grain yield of maize in waterlogged soils could be due to high moisture content. Also, they explained that maize roots are confined to the top $30 \mathrm{~cm}$ of soil, which is most severely affected by water logging early in the season and moisture stress late in the season.

Maize grain yields as a result of drain depth varying from 3.49 to $6.33 \mathrm{t} \mathrm{ha}^{-1}$ and 2.37 to $6.23 \mathrm{t} \mathrm{ha}{ }^{-1}$ with fertilizer ammonium sulfate and urea application, respectively. Ammonium sulfate resulted in significant yield increase over urea in the study site and this increase in yield was on average by $13.20 \%$ (Table 2). Fertilizer $\mathrm{N}$ utilization is affected by the $\mathrm{N}$ source. The significant effects of combined drain depth and $\mathrm{N}$ source on grain yields were higher in the case of AS than urea in plots without drainage. This is due to denitrification and lower $\mathrm{N}$ supply in the case of urea in the undrained plots, leading to reduction in both grains and stover yields (Table 2). 
Effect of Drain Depth of Vertisols, Nitrogen Source and Time of Application on Yield and Yield Components of Maize (Zea Mays L.) in Ambo, Western Ethiopia

Table 2. Interaction effect of drain depth and nitrogen source on maize grain and stover yield $\left(t h^{-1}\right)$, harvest index and thousand grain weight ( $g$ ) of maize grown on Vertisols at Ambo.

\begin{tabular}{|c|c|c|c|c|c|c|c|c|c|c|c|c|}
\hline \multirow{2}{*}{$\begin{array}{l}\text { Drain } \\
\text { depth } \\
\text { (cm) }\end{array}$} & \multicolumn{3}{|c|}{$\mathrm{N}$ sources } & \multicolumn{3}{|c|}{ N sources } & \multicolumn{3}{|c|}{ N sources } & \multicolumn{3}{|l|}{$\mathrm{N}$ sources } \\
\hline & Urea & AS & Mean & Urea & AS & Mean & Urea & AS & Mean & Urea & AS & Mean \\
\hline & \multicolumn{3}{|c|}{ Grain yield $\left(\mathrm{t} \mathrm{ha}^{-1}\right)$} & \multicolumn{3}{|c|}{ Stover yield $\left(\mathrm{t} \mathrm{ha}^{-1}\right)$} & \multicolumn{3}{|l|}{ HI (\%) } & \multicolumn{3}{|l|}{ TGW (g) } \\
\hline 0 & $2.37 \mathrm{f}$ & $3.49 \mathrm{e}$ & $2.93 \mathrm{~d}$ & $5.09 \mathrm{c}$ & $5.06 \mathrm{c}$ & $5.07 \mathrm{c}$ & $34.70 \mathrm{c}$ & $34.70 \mathrm{c}$ & $34.70 \mathrm{c}$ & $305.17 \mathrm{f}$ & $305.00 \mathrm{f}$ & $305.08 \mathrm{~d}$ \\
\hline 15 & $3.41 \mathrm{e}$ & $4.31 \mathrm{~d}$ & $3.86 \mathrm{c}$ & $5.77 \mathrm{c}$ & $6.57 \mathrm{~b}$ & $6.17 \mathrm{~b}$ & $37.20 \mathrm{c}$ & $41.70 \mathrm{~b}$ & $39.45 b$ & $317.50 \mathrm{ef}$ & $327.17 \mathrm{ef}$ & $322.33 \mathrm{~cd}$ \\
\hline 30 & $4.63 \mathrm{~d}$ & $5.23 c$ & $4.93 \mathrm{~b}$ & $6.53 \mathrm{~b}$ & 7.07ab & 6.80ab & $42.20 \mathrm{ab}$ & $43.80 \mathrm{a}$ & $44.00 \mathrm{a}$ & $343.17 \mathrm{de}$ & $368.17 \mathrm{~cd}$ & $355.67 \mathrm{bc}$ \\
\hline 45 & $5.72 b c$ & $5.92 \mathrm{ab}$ & $5.82 \mathrm{a}$ & $6.94 \mathrm{ab}$ & $7.57 \mathrm{a}$ & $7.25 \mathrm{a}$ & $42.50 \mathrm{~b}$ & $44.70 \mathrm{ab}$ & $43.10 \mathrm{a}$ & $359.00 \mathrm{~cd}$ & $400.33 \mathrm{ab}$ & $379.66 \mathrm{ab}$ \\
\hline 60 & $6.23 \mathrm{ab}$ & $6.33 a$ & $6.28 \mathrm{a}$ & $7.06 \mathrm{ab}$ & $7.54 a$ & $7.30 \mathrm{a}$ & $42.30 \mathrm{~b}$ & $44.80 \mathrm{ab}$ & $43.45 a$ & $373.67 b c$ & $423.83 a$ & $398.75 a$ \\
\hline Mean & 4.47 & 5.06 & 4.76 & 6.28 & 6.76 & 6.52 & 39.78 & 41.94 & 40.94 & 339.70 & 364.90 & 352.29 \\
\hline $\begin{array}{l}\text { LSD } \\
(0.05) \\
\end{array}$ & \multicolumn{2}{|c|}{ DDXNS $=0.58$} & $\mathrm{D}=0.82$ & \multicolumn{2}{|c|}{ DDXNS $=0.70$} & $\mathrm{D}=0.98$ & \multicolumn{2}{|c|}{$\mathrm{DDXNS}=0.04$} & $\mathrm{D}=0.02$ & \multicolumn{2}{|c|}{ DDXNS $=27.79$} & $\mathrm{D}=39.31$ \\
\hline $\begin{array}{l}\mathrm{CV} \\
(\%)\end{array}$ & \multicolumn{3}{|l|}{12.84} & \multicolumn{3}{|l|}{11.16} & \multicolumn{3}{|l|}{10.12} & \multicolumn{3}{|l|}{8.35} \\
\hline
\end{tabular}

Means within a column followed by the same letter(s) are not significantly different at 5\% probability.

$\mathrm{AS}=$ Ammonium sulfate; $\mathrm{HI}=$ Harvest index; $\mathrm{TGW}=$ Thousand grain weight $\mathrm{DD}=\mathrm{Drain}$ depth; $\mathrm{NS}=$ Nitrogensource

The time of $\mathrm{N}$ application had significant effects on the grain yield. With respect to grain yields, pairwise comparisons of treatments showed that thrice split application of nitrogen source resulted in higher grain yield than twice split application (Figure 1). The highest mean grain yield (4.98 $\left.\mathrm{t} \mathrm{ha}^{-1}\right)$ was obtained from thrice split application of $\mathrm{N}$ fertilizers with an increment of $9.69 \%$ over twice application. Thomas (1998) also found that delaying at least one-half of the applied $\mathrm{N}$ fertilizer until 4 to 6 weeks after planting resulted in improved efficiency from maize production on soils with poor drainage. In undrained plots less $\mathrm{N}$ was available for the remaining parts of the growing season than in drained plots. Moreover, the saturated root environment may have hindered root development in these soils, which further impeded the nutrient uptake. Although early $\mathrm{N}$ deprivation of maize plant results in serious reduction of grain yield (Girardin et al., 1987), $\mathrm{N}$ requirements of maize during early stages of development are not large. The significant interaction effect of AS and drain depth on grain yields in which AS resulted in higher yields than did urea in the upper soil layer $(0-30 \mathrm{~cm})$ are likely due to denitrification losses in the upper soil layer. Usually, the relative effectiveness of $\mathrm{N}$ sources is determined by interactions between fertilizer properties and soil properties as well as by the influence of management and crop species (Chien et al., 1990).

\subsection{Stover Yield}

The analysis of variance showed that drain depth, $\mathrm{N}$ source and time of application, and the interaction between drain depth and nitrogen source had significantly $(\mathrm{P} \leq 0.05)$ affected maize stover yield (Table 2 and Figure 1). However, the interaction between drain depth and $\mathrm{N}$ timing and $\mathrm{N}$ source and time of application were not significant.

The increase in drain depth resulted in higher maize stover yield. Application of fertilizer AS coupled with 30, 45 and $60 \mathrm{~cm}$ deep drain improved maize stover yield than urea application coupled with 0 and $15 \mathrm{~cm}$ deep. The highest stover yield $\left(7.54 \mathrm{t} \mathrm{ha}^{-1}\right)$ was recorded in fertilizer AS coupled with deep drain depth of $60 \mathrm{~cm}$, with an increment of $48.13 \%$ in stover yield of maize compared to urea in undrained plots which is a common farmer's practice (Table 2). This is due to higher $\mathrm{N}$ losses from urea than from AS under waterlogged conditions. These results are in agreement with Griggs et al. (2007) who reported that volatilization of ammonium nitrate from urea was much higher than that of AS during 20 days after $\mathrm{N}$ application. Likewise, timing of $\mathrm{N}$ application considerably influenced maize stover yield. Thrice split application of $\mathrm{N}$ resulted in higher stover yield than twice split $\mathrm{N}$ application (Figure 2). The highest stover yield $\left(6.57 \mathrm{t} \mathrm{ha}^{-1}\right)$ was obtained from thrice split application of $\mathrm{N}$ source, whereas the lowest stover yield $\left(6.41 \mathrm{tha}^{-1}\right)$ was recorded from twice split application of $\mathrm{N}$ source. This is mainly attributed to synchronization of $\mathrm{N}$ availability with crop demand. These results are supported by Mughogo et al. (1990) who reported that split application of fertilizer $\mathrm{N}$ doubled the fertilizer use efficiency of $\mathrm{N}$ and resulting in 50\% increase in maize yield. The split application of $\mathrm{N}$ fertilizers to coincide with the critical stages of crop growth has been shown to increase $\mathrm{N}$ use efficiency (Legg and Meisinger, 1982). 


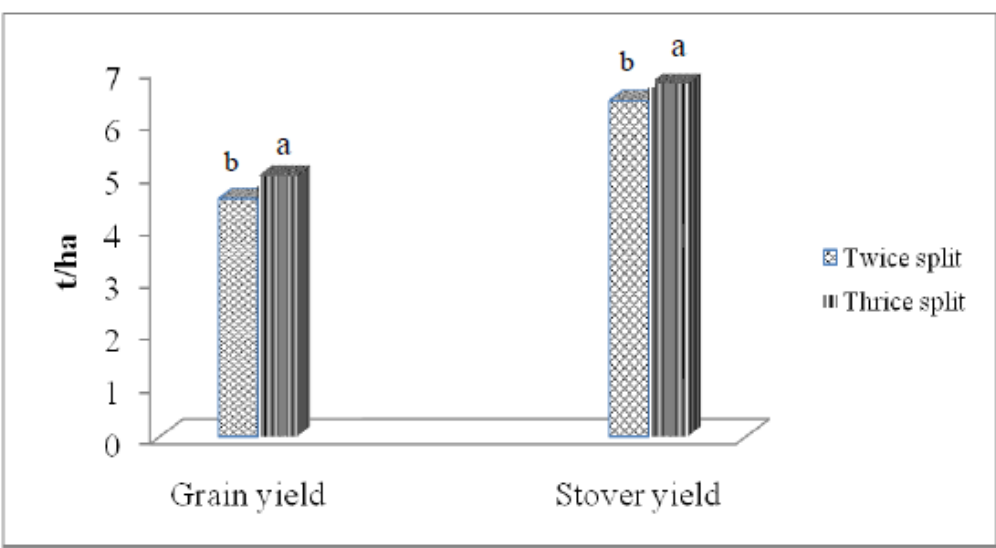

Figure 1. Effect of time of nitrogen application on grain and stover yields of maize grown on Vertisols at Ambo. Bars for each parameter with different letters are significantly different at $5 \%$ probability level.

\subsection{Thousand Grain Weight}

The analysis of variance showed that thousand grain weight was significantly affected $(\mathrm{P} \leq 0.05)$ by drain depth, $\mathrm{N}$ source and time of application, and interaction effect of drain depth and nitrogen source (Table 2 and Figure 2). However, the interaction effect of $\mathrm{N}$ source and timings and drain depth and time of $\mathrm{N}$ application had no significant influence on thousand grain weight.

The thousand grain weight is an important yield component that helps a lot in grain yield estimate. Generally, thousand grain weight increased as drain depth increases, the maximum 1000 grain weight $(423.83 \mathrm{~g})$ was obtained from fertilizer AS application coupled with deep drain depth of $60 \mathrm{~cm}$, whereas the minimum (305.00 g) was recorded from urea application in undrained plots (Table 2). Generally, application of ammonium sulfate resulted in significantly higher thousand grain weight than urea application. Similarly, timing of $\mathrm{N}$ application also significantly affected thousand grain weights (Figure 2). The thousand grain weight rose from $333.13 \mathrm{~g}$ with twice split application of $\mathrm{N}$ to $371.47 \mathrm{~g}$ with thrice split application. These results are quite in line with the finding of Miller et al. (1975) and Sharma (1980), who concluded that time of fertilizer application at different growth stages of maize significantly, affected the 1000 grain weight.

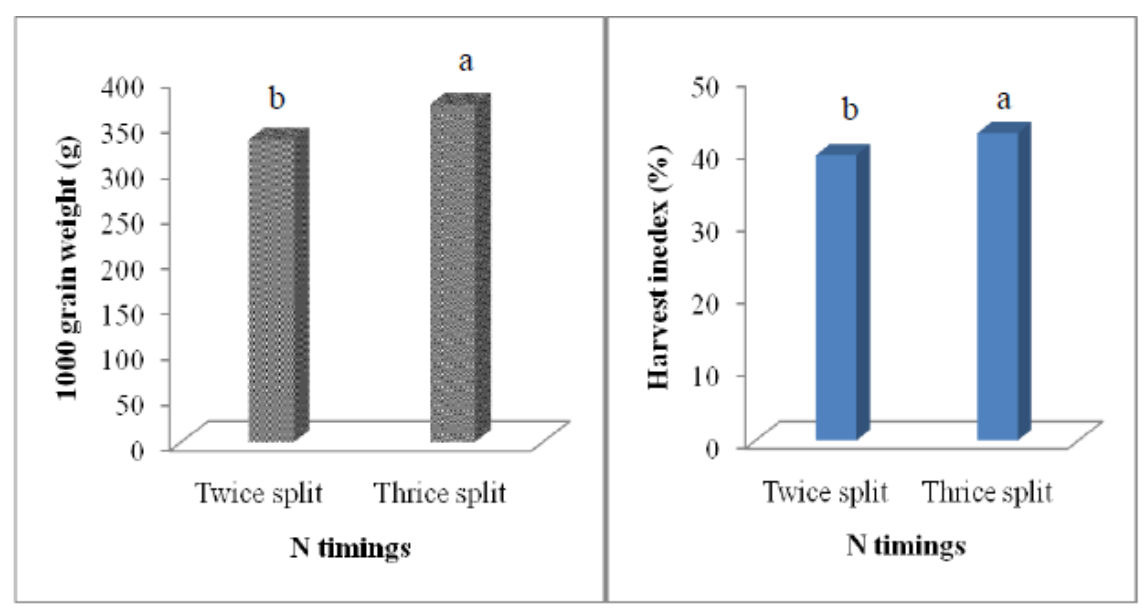

Figure 2. Effect of time of nitrogen application on harvest index and thousand grain weight of maize grown on Vertisols at Ambo. Bars for each parameter with different letters are significantly different at $5 \%$ probability level.

\subsection{Harvest Index}

The analysis of variance revealed that drain depth, nitrogen source and time of application, that interaction effect of drain depth and nitrogen source had significantly $(\mathrm{P} \leq 0.05)$ affected HI (Table 2 and Figure 2). On the other hand, HI was not significantly affected by the interaction effect of $\mathrm{N}$ source and timings, and drain depth and time of $\mathrm{N}$ application.

Application of AS substantial improved HI as compared to urea application. The mean HI values varied from $34.70 \%$ to $44.80 \%$ for the fertilizer AS application and from 34.70 to $42.30 \%$ for urea. 
The highest HI (44.80\%) was obtained from plots treated with AS at deep drain depth of $60 \mathrm{~cm}$. On the other hand, the lowest HI (34.70\%) was obtained from plots treated with urea which was undrained (Table 2). The harvest index values in the present study was similar with those reported by Van Duivenbooden et al. (1996), who gave a range from 32 to $48 \%$, with a mean of $40 \%$. Time of $\mathrm{N}$ application greatly influenced $\mathrm{HI}$, thrice split application of $\mathrm{N}$ source resulted in higher $\mathrm{HI}(42.40 \%)$ than twice split application (39.40\%) of N source (Figure 2).

\section{Conclusion}

Drainage plays an important role in controlling soil moisture level in the rhizosphere, root development and availability of nitrogen in the Vertisols. The effects of different drain depth and nitrogen source on maize performance were investigated. Drains, 45 and $60 \mathrm{~cm}$ deep resulted in maximum plant density, plant height and deeper root depth than the 0,15 and $30 \mathrm{~cm}$ drains. Grain and stover yields, 1000 grains weight and HI were significantly improved by drain depths, nitrogen source and timing of nitrogen application. The maximum mean grain yield, stover yield, 1000 grain weight, and HI were obtained from drain depth $60 \mathrm{~cm}$ along with fertilizer AS application; however, these yields are statistically on par with $45 \mathrm{~cm}$ deep drain. Similarly, thrice split application of N source gave better grain and stover yields, 1000 grain weight and HI than twice at 45 and $60 \mathrm{~cm}$ drain depths and the lowest were obtained from undrained treatments. From the present study, it can concluded that drain depth of $45 \mathrm{~cm}$ coupled with AS and thrice split application could successfully enhance maize production on Vertisols in Ambo and similar areas.

\section{ACKNOWLEDGEMENT}

The author would likes to acknowledge Ambo University for financial and technical supports for the research work.

\section{REFERENCES}

[1] Akbar H, Miftahullah M T, and Jan Ihsanullah A (2002) Yield potential of sweet corn as influenced by different levels of nitrogen and plant population. Asian J. Plant Sci., 1: 631-633.

[2] Andreini M S and Steenhuis T S (1990) Preferential paths of flow under conventional and conservation tillage. Geoderma, 46: 85-102.

[3] Asiedu E K and Bonsu M (2001) Analysis of the drying efficacy of some Vertisols management technologies using simple model. Ghana Jnl agri. Sci. 34: 77-84.

[4] Aulakh M S and Mosier A R (1992) Soil denitrification-Significant, measurement, and effects of management. Adv. Soil Sci., 18: 1-57.

[5] Barraclough S C, Jarvis G, Davies P and Williams J (1992) The relation between fertilizer nitrogen applications and nitrate leaching from grazed grassland. Soil Use and Management, 8(2): 51-56.

[6] Bayene D 1988 Soil fertility research on some Ethiopian Vertisols. pp. 223-239. In: S. C. Jutzi, S.C. Haque and I. Malture (eds.). Management of Vertisols in sub-Saharan Africa. I LCA: Addis Ababa.

[7] Bedru B, Endeshaw H, Bayissa G, Gemechu S, Habte J, Tolera K, Gudeta N, Belete T, Lealem T, Gezahegn B, Dagne W, Tsige D (2012) Participatory on-Farm Maize Technology Evaluation and Promotion in Ethiopia. pp. 203. In: Mosisa, W., S. Twumasi A., W. Legesse, T. Berhanu, W. Dagne, and B.M. Prasanna (eds.). Meeting the Challenges of Global Climate Change and Food Security through Innovative Maize Research Proceedings of the $3^{\text {rd }}$ National Maize workshop of Ethiopia, 18-20, April 2011. Addis Ababa, Ethiopia.

[8] Berhanu D (1985) The Vertisols of Ethiopia their properties, classification and management. $5^{\text {th }}$ Meeting of the Eastern African Soil Correlation and Land Evaluation Sub-Committee, 4-10 December 1983, Wad Medani Sudan. World Soil Resources Report 56. FAO (Food and Agriculture Organization of the United Nations), Rome.

[9] Brown D A and Scott H D (1984) Dependence of crop growth and yield on root development and activity. In: Roots, nutrient and water influx, and plant growth. ASA special publication 49: 101-136.

[10] Chien S H and Friesen D K (1990) A discussion of the methods for comparing the relative effectiveness of phosphate fertilizers varying in solubility. Fertilizer Research, 24: 149-157. 
[11] Central Statistical Agency (2010) Reports on area and crop product on forecasts for major grain crops (For private peasant holding, Meher Season). The FDRE Statistical Bulletins (1990-2010), CSA, Addis Ababa, Ethiopia.

[12] Engdawork A 2002 Characteristics, classification and potentials of soils in Werkayia area, South Welo, Ethiopia. SINET: Ethiopian Journal of Science, 25(1): 45-70.

[13] Esechie H A (1992) Effect of planting density on growth and yield of irrigated maize in the Batinah coast region of Oman. J. Agri. Sci., 119: 165-169.

[14] Food and Agriculture Organization (2008) Food and Agriculture Organization of the United Nations (FAO) Report, 2008. Rome, Italy.

[15] Girardin P, Tollenaar M, Deltour R and Muldoon J (1987) Temporary N starvation in maize (Zea mays L.) effects of development, dry matter accumulation and grain yield. Agronomie, 7(4): 289296.

[16] Griggs B R, Norman R J, Wilson C E and Slaton N A (2007) Ammonia volatilization and nitrogen uptake for conventional and conservation tilled dry-seeded, delayed-flood rice. Soil Sci. Soc. Am. J. 71: 745-751.

[17] Hassen A (2000) Effect of plant population density on yield and yield components of 8 Egyptian maize hybrids. Bull. Faculty Agric. Uni. Cairo., 51: 1-16.

[18] Jaetzold R and Schmidt H (1992) Farm Management Handbook of Kenya, Vo III/A. West Kenya. MoA: Nairobi, Kenya.

[19] Jutzi S and Abebe M (1987) Improved agricultural utilization of Vertisols in Ethiopian Highlands: An Institutional approach. In Management of Vertisols under Semi-arid conditions. IBSRAM Proc. No.6, pp 173-183. Bangkok: IBSRAM.

[20] Legg J O and Meisinger J J (1982) Soil nitrogen budgets. pp. 22: 503-557. In: Nitrogen in Agriculture Soils. (ed.). Stevenson, F.J. America Society of Agronomy Journal, Madison, Wisconsin, USA.

[21] Mesfin A (1980) State of soil science development for agriculture in Ethiopia. Ethiopian Journal of Agricultural Sciences 2(2): 139-157.

[22] Miller H F, Kawanaugh J and Thomus G W (1975) Time of application and yield of corn in wet alluvial soils. Agron. J., 67: 401-4.

[23] Morton W H (1977) Geological notes for the field excursion. In: Reports of the Second Meeting of the Eastern Africa Sub-Committee for soil Correlation and Land Evaluation, Addis Ababa, Ethiopia, 25-30 October 1976. Soil Resource Reports No. 47. FAO (Food and Agricultural Organization), Rome. pp 96-100.

[24] Muchena F N and Ikitoo E C (1992) Management of Vertisols in semiarid areas of Kenya: the effect of improved methods of surplus soil/surface water drainage on crop performance. Report of the 1992 Annual Meeting on Africaland Management of Vertisols in Africa. Network document No. 3. IBSRAM, Bangok.

[25] Mughogo S K, Christianson C B, Stumpe J M and Vlek P L G (1990) Nitrogen efficiency at three sites in Nigeria as affected by N source and management. Trop. Agric. (Trinidad), 67(2): 127-132.

[26] SAS Institute (2001) The SAS system for windows, version 8.2. SAS Institute Inc. Cary, NC, USA.

[27] Sharma R N (1980) Effect of planting techniques and time and method of fertilizer application on Maize (Ganga - 3). Indian J. Agron., 25: 359 -555.

[28] Sigunga D O, Janssen B H and Oenema O (1997) Fertilizer nitrogen use efficiency and nutrient uptake by maize (Zea mays L.) in Vertisols in Kenya $\mathrm{PhD}$ thesis. Wageningen Agricultural University, The Netherlands.

[29] Sigunga D O, Janssen B H and Oenema O (2002) Effect of improved drainage and nitrogen source on yields, nutrient up-take and utilization efficiencies by maize (Zea mays, L.) on Vertisols in sub-humid environments. Nutrient Cycling in Agro-ecosystems, 62 (3). pp 263-275.

[30] Smaling E M A and Bouma J (1992) Bypass flow and leaching of nitrogen in a Kenyan Vertisols at the onset of the growing season. Soil Use and Management, 8: 44-48.

[31] Tekalign M, Haque I and Kamara C S (1988) Phosphorus status of some Ethiopian highland Vertisols. pp. 232-252. In: Jutzi S C, Haque I, McIntire J and Stares J E S (eds.). Management of 
Effect of Drain Depth of Vertisols, Nitrogen Source and Time of Application on Yield and Yield Components of Maize (Zea Mays L.) in Ambo, Western Ethiopia

Vertisols in sub-Saharan Africa. Proceedings of a conference held at ILCA, Addis Ababa Ethiopia, 31 August - 4 September 1987. ILCA (International Livestock Centre for Africa), Addis Ababa, Ethiopia.

[32] Thomas G W (1998) Delayed nitrogen applications on corn. Soil Sci. News and Views, 2: 1-2.

[33] Trenton F, Stanger S and Joseph G L (2006) Optimum plant population of Bacillus thuringiensis and non Bacillus thuringiensis corn in Wisconsin. Agron. J., 98: 914-921.

[34] Van Duivenbooden N, De Wit C T and Van Keulen H (1996) Nitrogen, phosphorus and potassium relations in five major cereals reviewed in respect to fertilizer recommendations using simulation modelling. Fert. Res. 44:37-49.

[35] Wiesler F and Horst W J (1994a) Root growth and nitrate utilization of maize cultivars under field conditions. Plant and Soil, 163: 267-277. 